\title{
ANALISIS CIRI KEPEMIMPINAN HAMBA SERTA RELEVANSINYA PADA MASA KINI BERDASARKAN INJIL MATIUS 20:26-28
}

\author{
Ferry Pigai \\ sttjaffraymakassar@yahoo.co.id
}

\begin{abstract}
ABSTRAK
Adapun yang menjadi tujuan penulisan dari penulisan penulisan ini adalah: Pertama, untuk memberikan penjelasan tentang ciri-ciri kepemimpinan hamba berdasarkan Injil Matius 20:26-28. Kedua, untuk membuktikan bahwa kepemimpinan hamba sangat relevan bagi kepemimpinan pada masa kini.

Metode penelitian yang penulis gunakan dalam menulis penulisan ini ada beberapa di antaranya adalah: Pertama, metode teknik analisis teks, dalam hal ini penulis menggunakan metode hermeneutik/eksegesis langsung dari Alkitab. Kedua, berdasarkan teori ilmiah, dalam hal ini penulis menggunakan buku-buku yang berkaitan langsung dengan pembahasan penulisan ini. Ketiga, penulis juga meneliti dengan metode penelitian lewat perpustakaan yaitu buku-buku dan penulisan serta diktat-diktat perkuliahan.

Berdasarkan seluruh pembahasan penulisan pada bab-bab sebelumnya, maka dapat ditarik beberapa kesimpulan sebagai berikut: Pertama, kepemimpinan hamba mempunyai beberapa ciri-ciri khusus; pertama, harus menjadi pelayan. Artinya bahwa seorang pemimpin bukan saja hanya memimpin, tetapi juga harus membuktikan dirinya sebagai seorang pelayan. Kedua, harus menjadi hamba. Artinya bahwa seorang pemimpin bukan saja hanya memimpin orang dan memerintah saja, tetapi juga harus membuktikan dirinya sebagai seorang hamba yang merelakan diri sepenuhnya bagi kebutuhan bawahannya. Ketiga, ada harga yang harus dibayar, yaitu penyangkalan diri, bukan hanya menerima pelayan dari bawahan, tetapi juga merelakan diri dan hidupnya untuk melayani orang lain. Kedua, kepemimpinan hamba masih dan sangat relevan bagi kepemimpinan saat ini, baik di dunia kepemimpinan sekuler, secara khusus dalam dunia kepemimpinan Kristen saat ini. Kepemimpinan Yesus sangat relevan dalam kepemimpinan gereja dan kepemimpinan pada lembaga-lembaga Kristen.
\end{abstract}

Kata Kunci: Ciri Kepemimpinan Hamba 


\section{PENDAHULUAN}

\section{Latar Belakang Masalah}

Dewasa ini kepemimpinan sedamg mengalami suatu perubahan arah yang sangat mengejutkan bagi dunia kepemimpinan, baik dalam dunia kepemimpinan sekuler atau umum maupun dalam kepemimpinan Kristen. Seperti yang dikatakan oleh Sendjaya, "Dunia bisnis yang sering kali dipersepsi sebagai dunia sekuler, kotor dan keras semakin gencar mengadopsi prinsip dan pola yang biblikal/alkitabiah (meskipun mereka tidak menyadarinya). Sementara di pihak lain gereja malah mengaborsi prinsip dan pola tersebut." Inilah satu hal yang sedang terjadi dan belum disadari oleh para pemimpin, terutama para pemimpin Kristen yang telah memiliki dasar dalam kepemimpinannya, yaitu kepemimpinan Alkitabiah yang sesuai dengan ajaran Yesus. Pemimpin Kristen dewasa ini seolah-olah telah berbalik arah dari apa yang benar yang mereka tahu kepada apa yang dianggap baik dan menyenangkan mereka tanpa kembali pada dasar-dasar atau prinsip-prinsip alkitab yang sebenarnya. Eka Darmaputra mengatakan, "Keprihatinan yang sangat mendalam terhadap situasi kepemimpinan di Negara ini pada umumnya, dan gerejagereja kita pada khususnya. ... gereja-gereja kita, bergerak tanpa arah, serta sibuk diri tanpa makna. Dan hasilnya hanyalah kepenatan tanpa tahu untuk apa." ${ }^{2}$ Selain itu para pemimpin Kristen malah kompromi dengan hal-hal yang tidak sesuai dengan pola alkitabiah, dan mengunakan hal-hal yang tidak wajar serta negatif untuk memperoleh satu jabatan kepemimpinan yang lebih tinggi dan yang diharapkannya. Sadar atau tidak sadar bahwa tindakan ini adalah tindakan yang menimbulkan dosa dan selanjutnya akan menjadi momok dalam kepemimpinan. Satu pendapat menarik dari Leroy Eims yang menegaskan hal itu, "Apabila anda sebagai seorang pemimpin tidak berhasil menyelesaikan masalah dosa dalam hidup Anda sendiri, maka orang-orang yang bekerja dengan Anda akan segera kehilangan kepercayaan kepada Anda."

Melihat situasi seperti ini sebenarnya tidak sesuai dengan apa yang diharapkan dari seorang pemimpin Kristen, yang seharusnya menjadi figur dan panutan serta teladan bagi orang lain terutama

\footnotetext{
${ }^{\mathrm{I} S e n d j a y a, ~ K e p e m i m p i n a n ~ K r i s t e n: ~ K o n s e p, ~ K a r a k t e r ~ d a n ~ K o m p e t e n s i, ~(Y o g y a k a r t a: ~}$ Kairos Books, 2004), 20

${ }^{2}$ Eka Darmaputra, Kepemimpinan Dalam Perspektif Alkitabiah, (Yogyakarta: Kairos Books, 2005), 7.

${ }^{3}$ Leroy Eims, 12 Ciri Kepemimpinan yang Efektif, (Bandung: Yayasan Kalam Hidup, 2003), 17
} 
bawahannya. Ternyata hal ini disebabkan oleh karena kurangnya pemahaman serta kesadaran dari pemimpin itu sendiri ataupun disebabkan oleh kesombongan dan merasa lebih dari yang lain atau yang dipimpinnya dan merasa mampu dalam kepemimpinannya.

Perkembangan dan perubahan kepemimpinan yang terjadi dapat mengakibatkan suatu sistem kepemimpinan yang baik dan buruk, tergantung seorang pemimpin melihat situasi ini dan memanfaatkannya sebaik mungkin. Apakah kepemimpinan Kristen harus terus maju? Atau apakah diam di tempat? Atau juga jangan-jangan sedang mengalami suatu kemunduran dalam kepemimpinannya?

Seorang pemimpin akan terancam kehilangan jabatannya ketika dalam kepemimpinannya terdapat suatu cela. Untuk menghindari cela serta hal-hal yang membahayakan kepemimpinan, bagaimanakah ia harus bertindak?

Oleh sebab itu, penulis mencoba untuk membahas penulisan ini dengan judul yang mungkin dapat menjadi solusi bagi permasalahan yang sedang terjadi dan yang dihadapi saat ini oleh para pemimpin secara khusus pemimpin Kristen.

Berdasarkan itu, maka untuk tetap mempertahankan kepemimpinan Kristen serta membantu memberikan solusi yang alkitabiah, maka penulis membahasnya di bawah satu judul penulisan, yaitu: "Suatu Analisis Ciri Kepemimpinan Hamba Serta Relevansinya Pada Masa Kini Berdasarkan Injil Matius 20:26-28."

\section{Masalah Pokok}

Berdasarkan latar belakang masalah di atas, maka yang menjadi masalah pokok yang dapat diajukan dalam penulisan penulisan ini adalah:

Pertama, apakah ciri-ciri kepemimpinan hamba itu berdasarkan Injil Matius 20:26-28.?

Kedua, bagaimanakah relevansi kepemimpinan hamba pada masa kini?

\section{Batasan Penulisan}

Melihat situasi kepemimpinan yang sedang terjadi di tengah dunia kepemimpinan saat ini, khususnya dalam dunia kepemimpinan Kristen, maka dalam penulisan ini penulis membatasinya pada kepemimpinan hamba berdasarkan kepemimpinan Yesus dalam Injil Matius 20:26-28.

\section{Tujuan Penulisan}

Adapun yang menjadi tujuan penulisan dari penulisan penulisan ini adalah: 
Pertama, untuk memberikan penjelasan tentang ciri-ciri kepemimpinan hamba berdasarkan Injil Matius 20:26-28.

Kedua, untuk membuktikan bahwa kepemimpinan hamba sangat relevan bagi kepemimpinan pada masa kini.

\section{Manfaat Penulisan}

Manfaat penulisan yang dapat dicapai dalam penulisan penulisan ini adalah:

Pertama, bagi para pemimpin Kristen yang sedang memimpin agar menjadi masukan serta awasan dalam kepemimpinannya.

Kedua, bagi calon-calon pemimpin agar mendapat pola kepemimpinan yang alkitabiah.

Ketiga, untuk memenuhi salah satu syarat dalam penyelesaian tugas akhir pada Sekolah Tinggi Filsafat Theologia Jaffray Makassar.

Keempat, untuk memenuhi sebagian persyaratan dalam mencapai gelar sarjana Teologi pada Sekolah Tinggi Filsafat Theologia Jaffray Makassar.

\section{Metode Penelitian}

Metode penelitian yang penulis gunakan dalam menulis penulisan ini ada beberapa di antaranya adalah:

Pertama, metode teknik analisis teks, dalam hal ini penulis menggunakan metode hermeneutik/eksegesis langsung dari Alkitab.

Kedua, berdasarkan teori ilmiah, dalam hal ini penulis menggunakan buku-buku yang berkaitan langsung dengan pembahasan penulisan ini.

Ketiga, penulis juga meneliti dengan metode penelitian lewat perpustakaan yaitu buku-buku dan penulisan serta diktat-diktat perkuliahan. 


\section{ANALISIS CIRI-CIRI KEPEMIMPINAN HAMBA BERDASARKAN INJIL MATIUS 20:26-28}

\section{Menjadi Pelayan (Matius 20:26) Arti Kata Pelayan}

Matius 20:26, menurut Alkitab terjemahan baru, "Tidaklah demikian di antara kamu. Barangsiapa ingin menjadi besar di antara kamu, hendaklah ia menjadi pelayanmu." Sedangkan menurut alkitab terjemahan sehari-hari, "Tetapi di antara kalian lain halnya. Siapa yang ingin menjadi pemimpin harus menjadi pelayan."

Peristiwa pada ayat 20 sampai dengan ayat 28 ini terjadi saat mereka dalam perjalanan hendak pergi ke Yerusalem (20:17), namun di tengah perjalanan Yesus dan murid-murid-Nya, datanglah ibu Yakobus dan Yohanes memohon supaya kedua anaknya mendapat tempat yang istimewa di dalam kerajaan Allah.

Ayat 26 ini tidak terlepas dari ayat sebelumnya, yaitu ayat 20 sampai dengan ayat yang ke 25. Latar belakang munculnya ayat 26 akibat permohonan ibu Yakobus dan Yohanes agar anak-anaknya diberi tempat yang terhormat di dalam kerajaan Allah. Lalu Yesus menjawabnya dalam ayat 22 dan 23, "Kamu tidak tahu apa yang kamu minta." Dalam Alkitab bahasa sehari-hari, menjelaskan bahwa Yesus berpaling kepada Yakobus dan Yohanes, serta bertanya, "Sanggupkah kalian minum dari cawan yang pahit yang tidak lama lagi akan Kuminum?" Pertanyaan balik dari Yesus ini seolah-olah menantang para murid khususnya Yakobus dan Yohanes, namun setelah itu menurut tafsiran Alkitab Perjanjian Baru bahwa Yesus berkata. "Bukan hak-Ku menetapkan seseorang pada tempat terhormat dalam kerajaan." ${ }^{4}$ Pada bagian lain dijelaskan, "Mereka mengira bahwa kedudukan yang tinggi dalam kerajaan itu dapat diperoleh tanpa penderitaan dan bahwa Yesus dapat mengatur tempat dalam kerajaan itu." Dengan demikian dalam ayat 24 muncullah amarah dari para murid yang lain kepada kedua murid itu. Inilah yang menjadi alasan bagi Yesus untuk mengajar mereka tentang arti kepemimpinan seperti yang dijelaskan dalam Tafsiran Alkitab Perjanjian Baru, "Kemarahan para murid yang lain memberikan kesempatan kepada Yesus untuk mengajar mengenai orang lain sebagai jalan untuk menjadi pemimpin dalam jemaat-Nya." ${ }^{\text {"Dari sinilah }}$

\footnotetext{
${ }^{4}$ Dianne Bergant dan Robert J. Karris, Tafsiran Alkitab Perjanjian Baru, (Yogyakarta: Kanisius, 2006), 64.

${ }^{5}$ Tafsiran Alkitab Masa Kini Jilid 3, (Jakarta: BPK Gunung Mulia,1983), 110.

${ }^{6}$ Dianne Bergant dan Robert J. Karris, Tafsiran Alkitab Perjanjian Baru, (Yogyakarta: Kanisius, 2006), 64.
} 
akhirnya Yesus mengumpulkan semua murid-Nya lalu mengajarkan mereka tentang kepemimpinan mulai dari ayat 26-28.

Barangsiapa yang ingin menjadi pemimpin haruslah menjadi pelayan dan barangsiapa ingin menjadi besar di antara kamu hendaklah ia menjadi pelayanmu. Dari kedua pernyataan ini jelas bahwa yang ingin menjadi pemimpin atau menjadi yang terbesar ia harus terlebih dahulu menjadi seorang pelayan bagi yang lainnya. Kata "harus" dalam Alkitab Bahasa Indonesia Sehari-hari dan "hendaklah" dalam Alkitab Terjemahan Baru memberi satu perintah atau merupakan suatu kewajiban yang harus dilakukan bagi setiap orang yang ingin menjadi pemimpin. Hal itu sangat jelas ditegaskan oleh Yesus dalam ayat ini kepada murid-murid-Nya pada waktu itu. Menjadi pelayan merupakan hal yang wajib atau harus dilakukan bagi mereka yang ingin menjadi pemimpin dan hal itu harus selalu tampak dalam setiap pribadi yang ingin menjadi pemimpin.

Kata "pelayanmu" atau "pelayan." Kata pelayan berasal dari kata

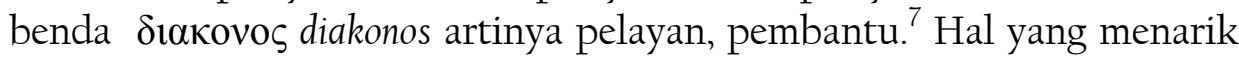
pada kata ini adalah kata tunggal yang artinya dikhususkan hanya untuk seorang yang ingin menjadi pemimpin dan bukan untuk semua orang dalam arti khusus. Kata pelayan juga merupakan kata benda yang berfungsi sebagai subjek pada ayat ini dan juga sebagai kata keterangan yang menjelaskan ayat ini bahwa seseorang tidak bisa menjadi pemimpin atau yang besar diantara orang lain jika ia tidak menjadi seorang pelayan terlebih dahulu. Jadi, dalam hal ini menjadi pelayan sebelum menjadi pemimpin mempunyai pengaruh yang kuat dalam sebuah kepemimpinan. Hal lain yang menarik pada ayat ini adalah bahwa kepemimpinan atau yang ingin menjadi besar itu tidak ditentukan siapa dia atau dengan kata lain bisa dapat dipastikan orang yang akan menjadi pemimpin dan siapa dia orangnya tidak ditentukan sebelumnya baik oleh status maupun derajatnya pada lingkungan di mana ia berada.

Kata "di antara" pada ayat 26 menunjukkan dalam jumlah orang yang ada tanpa melihat latar belakang pribadinya untuk menjadi seorang pemimpin, selanjutnya dalam jumlah orang tersebut ada yang akan muncul dengan sendirinya ketika ia mau menjadi pelayan bagi yang lain. Alasan akan muncul dengan sendirinya adalah salah satu orang di antara sekian orang, kata "barangsiapa" menunjukan atau kata tunggal yang artinya dari sekian banyak orang dalam satu kelompok pasti ada seorang yang menjadi pemimpin, dalam kelompok itu semuanya sedang dan terus berusaha untuk bisa menjadi yang besar atau sebagai pemimpin, dalam kasus ini orang sebagai objek dari pemimpin atau besar dengan kata lain orang tidak perlu mencari kepemimpinan atau menjadi yang besar

\footnotetext{
${ }^{7}$ Hasan Sutanto, Iterlinier Konkordansi Yunani-Indonesi, (Jakarta:Lembaga Alkitab Indonesia, 2003), 506.
} 
karena kepemimpinan dan kebesaran yang akan mencari orang-orang yang layak menjadi pemimpin.

Dalam ayat ini juga terdapat kata "besar" dalam bahasa Yunani adalah $\mu \dot{\varepsilon} \gamma \alpha \varsigma$ megas kata ini menerangkan sesuatu yang sangat atau lebih dari yang biasa-biasa atau mempunyai satu kelebihan khusus jika dibandingkan dengan yang lain. Interlinier Konkordansi Yunani-Indonesia memberi arti bahwa megas adalah besar, agung, panjang, luas, lanjut, kaya, nyaring, terang, penting, keras, sangat, dahsyat." 8 Ayat ini menunjukkan suatu kekuatan atau pengaruh kekuasaan yang akan dimiliki pada seorang pemimpin. Megas inilah yang dicari dari setiap orang yang ingin menjadi pemimpin bahkan yang sudah menjadi pemimpin. Pada konteks ini Yesus menawarkan hal itu bagi para murid dan siapa saja yang ingin menjadi terbesar pada suatu kelompok atau organisai. Dalam konteks ini Yesus akan memberikan atau membuat seseorang menjadi yang besar asal ia besedia menjadi hamba, seperti penjelasan sebelumnya bahwa megas adalah subjek yang akan mencari seseorang yang adalah objeknya jikalau seseorang telah menjadi diakonos (pelayan).

Kata berikutnya adalah kata "menjadi pelayan" khususnya kata menjadi, kata ini berasal dari kata $\varepsilon \sigma \tau \alpha \iota$ estai yang berarti akan menjadi, namun kata estai sendiri berasal dari kata dasar eı eimi yang artinya "adalah, terdapat, tinggal, seperti, artinya." Jadi, kata ini menunjuk kepada seseorang pada waktu itu dan sekarang yang menjadi seorang pelayan dan berada serta tinggal menjadi pelayan, bukan hanya untuk satu masa atau satu waktu tertentu, namun untuk masa depan dan seterusnya menjadi pelayan sepanjang masa kepemimpinannya. Artinya bahwa jika seseorang sudah berada pada satu kepemimpinan ia harus terus menunjukan diri bukan hanya sebagai seorang pemimpin saja namun dia juga harus menunjukan atau membuktinyatakan diri sebagai seorang pelayan.

\section{Fungsi Pelayan}

Berdasarkan penjelasan arti kata hamba di atas, maka secara tidak langsung dapat ditemui fungsi hamba yakni mengerjakan atau menunjukkan prinsip-prinsip sebagai seorang pelayan. Kata pelayan menurut Kamus Besar Bahasa Indonesia adalah "1) membantu menyiapkan (mengurus) apa yang diperlukan seseorang; meladeni, 2) menerima (menyambut) ajakan (tantangan, serangan), 3) mengendalikan, melaksanakan penggunaan." Dalam pengertian ini yang digunakan

\footnotetext{
${ }^{8}$ Ibid., 506.

${ }^{9}$ Kamus Besar Bahasa Indonesia, s.v. "Layan /Melayani” (Jakarta: Balai Pustaka, 2001)
} 
adalah pada arti pertama menurut kamus di atas yaitu membantu menyiapkan dan mengurus apa yang diperlukan seseorang. Jadi, dalam hal ini mulailah jelas bahwa fungsi pelayan adalah membantu seseorang menyiapkan apa yang menjadi keperluannya dan jika dalam konteks kelompok, maka seorang pelayan juga menyiapkan dan mengerjakan apa yang menjadi kebutuhan kelompok dan bukan lagi pada satu orang.

Dalam kaitannya dengan ayat 26 sebenarnya Yesus ingin mengajarkan para murid-Nya untuk melihat dan mengingat kembali apa yang sudah Yesus lakukan dan yang seharusnya menjadi teladan bagi mereka dalam hal melayani. Ensiklopedi Alkitab Masa Kini jilid I menjelaskan, "Teladan pelayanan Kristen disajikan dalam teladan pelayanan Kristus, yang datang bukan untuk dilayani. melainkan untuk melayani (Mat 20:28; Mrk 10:45); kata kerja yang dipakai dalam ayatayat ini ialah diakonein, yang melukiskan pelayanan di meja makan, dan mengingat kembali peristiwa tatkala Yesus membasuh kaki muridmurid-Nya (Yoh 13:4)."10 Apa yang Yesus lakukan bagi para murid ini merupakan satu fungsi dari seorang pelayan dan hal itu Yesus buktikan serta menunjukkannya kepada para murid-Nya sebagai suatu teladan. Jadi, jelaslah bahwa fungsi seorang pelayan adalah mengerjakan apa yang menjadi kebutuhan orang lain, tidak mempedulikan posisinya atau tingkatnya dalam kelompok di mana ia harus melayani. Walaupun Yesus adalah guru mereka, namun Ia rela mengerjakannya bagi murid-muridNya. Peniel Maiaweng menjelaskan dalam bukunya Pemberdayaan Jemaat Menjadi Pelayan Jemaat mengatakan, "Kata pelayan diterjemahkan dari kata diakonos yang berarti orang yang mengadakan pemeliharaan atau orang yang mencukupi orang yang membutuhkan bantuan." Selanjutnya dijelaskan, "Diakonos adalah seorang yang menjalankan atau melaksanakan perintah orang lain. Pengertian pelayan lebih difokuskan kepada orang yang berkorban untuk melayani dan memenuhi kebutuhan orang lain." Jadi, dalam hal ini fungsi seorang pelayan sangat terlihat jelas bahwa ia bukan hanya menjalankan serta melaksanakan perintah orang lain, tetapi juga dibutuhkan suatu pengorbanan dari dirinya untuk orang lain dan kesejahteraan orang lain. Itulah fungsi seorang pelayan yang ingin menjadi pemimpin atau terbesar dalam suatu kelompok.

\footnotetext{
${ }^{10}$ Ensiklopedi Alkitab Masa Kini, (Jakarta:Yayasan Komunikasi Bina Kasih, 1992), 637.

${ }^{11}$ Peniel Maiaweng, Pemberdayaan Jemaat Menjadi Pelayan Jemaat, (Tenggarong: Sekolah Tinggi Teologi Tenggarong, 2004),47.

${ }^{12}$ Ibid., 47.
} 


\section{Dampak Menjadi Pelayan}

Dalam melakukan segala sesuatu pastilah terdapat dampakdampak khusus yang turut mempengaruhi segala sesuatu itu. Sebagai seorang pelayan, baik para pelayan umum maupun pelayan Kristen pastilah memiliki dampak yang diakibatkan oleh pelayanannya, baik secara positif maupun negatif.

Pada ayat 23, sepertinya ada satu dampak atau akibat yang terjadi jika seseorang ingin menjadi pelayan yaitu meminum cawan. Peniel Maiaweng berkata, “...cawan yang merupakan lambang dari penderitaan yang akan dialami oleh murid-murid dalam pelayanan yang mereka akan laksanakan." Jelas bahwa cawan yang dimaksud adalah penderitaan. Seseorang yang melayani Yesus pastilah akan menghadapi suatu penderitaan.

Seorang pelayan harus menyiapkan makanan atau kebutuhan hidup bagi orang lain. Bukan hanya yang dikenalinya ataupun keluarganya, tetapi semua orang yang membutuhkannya. Sebagai seorang pelayan ia harus bisa dan mampu melaksanakan hal itu. Ialah yang bertanggung jawab atas kebutuhan seseorang untuk memperpanjang hidupnya. Inilah dampak yang harus diterima dan dilaksanakan oleh seorang pelayan. Ia harus melaksanankan apa yang diperintahkan kepadanya untuk dilaksanakan tanpa membantah karena itulah fungsinya sebagai seorang pelayan yang menyiapkan segala sesuatu bagi orang lain yang membutuhkannya. Merupakan satu kesalahan apabila seorang pelayan melayani orang lain dengan motivasi yang salah atau skedar mencari mencari nama atau penonjolan diri.

\section{Manjadi Hamba (Matius 20:27) \\ Arti Kata Hamba}

Matius 20:27, "Dan barangsiapa ingin terkemukan di antara kamu, hendaklah ia menjadi hambamu."

Kata hamba dalam ayat 27 ini berfungsi sebagai kata benda yang sekaligus sebagai pokok dari ayat ini yang juga berfungsi sebagai subjek kalimat dan memberikan keterangan bagi ayat 27 ini. Artinya bahwa kata hamba sebagai pelengkapnya ayat 27 karena tanpa kata hamba sebenarnya percuma menjadi terkemuka sebab menurut ayat 27 ini hanya orang yang menjadi hambalah yang biasa menjadi terkemuka.

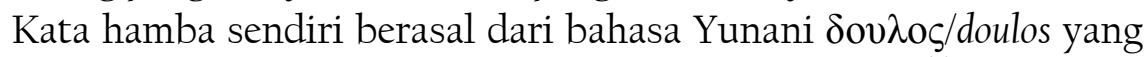
berarti "Hamba, pegawai raja, orang yang bergantung pada." ${ }^{\text {"14 Kata doulos }}$ ini dipakai di dalam Perjanjian Baru sebanyak 124 kali dan dipakai pada

\footnotetext{
${ }^{13}$ Ibid., 44.

${ }^{14}$ Hasan Sutanto, Interlinier Konkordansi Yunani-Indonesia, (Jakarta: Lembaga Alkitab Indonesia, 2003), 642.
} 
kasus yang berbeda-beda, namun dalam Matius 20:27 ini dipakai sebagai yang menjadi sentralitas atau pokok dalam ayat ini seperti penjelasan di atas.

Menurut Tafsiran Alkitab Masa Kini, "Istilah hamba dipakai sebagai tugas yang paling umum untuk tugas pelayanan Kristen dalam Perjanjian Baru dan setiap pelayan harus mengingat arti sebenarnya dari kata itu." ${ }^{15}$ Secara langsung pernyataan ini memerintahkan untuk kembali melihat arti kata hamba itu bahwa sebagai hamba dan pelayan Kristen diharuskan mengerjakan pelayanan sebagai hamba Tuhan Yesus.

Jadi, bagi orang yang ingin menjadi terkemuka ia harus terlebih dahulu menjadi hamba di antara yang lain, yaitu rela menjadi budak yang bergantung sepenuhnya kepada orang lain atau tuannya, maka ia akan menjadi yang terkemuka. Pdt. Peniel Maiaweng menjelaskan, "Kata hamba diterjemahkan dari kata doulos yang berarti budak atau orang yang terikat pada orang lain (tuannya), atau orang yang tidak berkuasa atas dirinya sendiri. Terjemahan lain dari kata doulos adalah tunduk, yang berhubungan dengan ketaatan dan kepatuhan dalam pengabdian"16 dalam buku Pemberdayaan Jemaat Menjadi Pelayan Jemaat juga dijelaskan, "Kata doulos juga seorang yang mengabdikan dirinya pada orang lain tanpa mempedulikan keinginan-keinginan pribadinya. Jadi, pengertian hamba lebih difokuskan kepada orang yang memiliki pengabdian dan terikat kepada pekerjaan yang dilaksanakannya dan mempertanggung jawabkannya kepada tuan pemiliknya." ${ }^{\prime 7}$ Inilah arti kata hamba atau budak, yaitu seseorang yang bekerja pada orang lain dan tidak berkuasa atas dirinya karena milik tuannya dan yang melaksanakan segala hal yang diperintahkan kepadanya.

\section{Fungsi Hamba}

Berdasarkan arti kata hamba di atas, maka sangat jelas secara tidak langsung bahwa fungsi hamba adalah sebagai seorang pekerja yang mengkhususkan dirinya kepada tuannya untuk menjadi pembatu atau budaknya. Dengan demikian, maka tugasnya ialah mengerjakan apa yang menjadi kebutuhan tuannya serta menjalankan perintah yang diberikan padanya, entah baik atau tidak baik perintah itu harus dilaksanakan. Ensiklopedi Alkitab Masa kini memberi penjelasan, "Budak, hamba atau pelayan artinya seseorang bekerja untuk keperluan orang lain, untuk

\footnotetext{
${ }^{15}$ Tafsiran Alkitab Masa Kini (Jakarta: Yayasan Komunikasi Bina Kasih, 1983), 110.

${ }^{16}$ Peniel Maiaweng, Pemberdayaan Jemaat Menjadi Pelayan Jemaat (Tenggarong: Sekolah Tinggi Teologi Tenggarong, 2004),47-48.

${ }^{17}$ Ibid., 48
} 
melaksanakan kehendak orang lain." ${ }^{18}$ Jadi, seorang budak atau seorang hamba tidak bekerja menurut keinginan hatinya, tetapi harus sesuai dengan aturan serta perintah yang diberikan oleh tuannya untuk dilaksanakan. Inilah salah satu fungsi seorang hamba/budak, ia tidak bekerja untuk diri sendiri dan tidak juga untuk keperluannya serta kepentingannya sendiri, tetapi selalu untuk tuannya.

Seorang hamba selalu menyenangkan tuannya dan selalu meletakkan dirinya serendah mungkin di bawah tuannya dan selalu siap melaksanakan perintah. Seorang hamba sebenarnya tidak menegenal lelah demi melaksanakan tanggung jawabnya. Itulah fungsi seorang hamba, yaitu taat kepada tuanya dan siap kapan saja waktunya untuk melayani tuannya. Hal yang sama dirasakan oleh Yesus, "Keberadaan Yesus sebagai pelayan dan hamba diamanatkan kepada murid-muridNya agar mereka mengabdikan diri kepada Allah yang wujudnya adalah hidup dalam ketaatan kepada Allah." ${ }^{19}$ Jadi, seorang pelayan Tuhan harus bisa memfungsikan atau mempraktekkan diri sebagai hamba yang mau tunduk dan juga melayani orang lain.

Oswald Sanders berkata,

Yang saya pikirkan ialah arti kata kepemimpinan yang ada pada pikiran Tuhan Yesus, ketika Ia berkata, "Barangsiapa ingin menjadi terkemuka di antara kamu, hendaklah ia menjadi hamba unutk semuanya", yaitu kepemimpinan dalam arti memberikan pelayanan sebesar-besarnya; ...yang tidak mengenal lelah dan terus-menerus memusatkan pada pekerjaan yang terbesar di dunia, yaitu membangun kerajaan Tuhan kita Yesus Kristus. ${ }^{20}$

Inilah fungsi seorang pelayan sekaligus sebagai seorang hamba dimana ia harus terus-menerus memberikan pelayanan yang sebesarbesarnya tanpa mengenal lelah dan terus-menerus memusatkan pelayanan pada pekerjaan yang terbesar dan mulian itu. Pada prinsipnya fungsi pelayan dan fungsi hamba mempunyai kemiripan, namun sebutan kedua kata ini yang membuatnya agak berbeda karena hamba atau budak mempunyai pengertian yang lebih rendah dibandingkan dengan pelayan, tetapi keduanya melayani orang.

\footnotetext{
${ }^{18}$ Ensiklopedi Alkitab Masa Kini (Jakarta: Yayasan Komunikasi Bina Kasih, 1992), 360.

${ }^{19}$ Peniel Maiaweng, Pemberdayaan Jemaat Menjadi Pelayan Jemaat (Tenggarong: Sekolah Tinggi Teologi Tenggarong, 2004),47-48.

${ }^{20}$ Oswald Sanders, Kepemimpinan Rohani (Bandung: Kalam Hidup, 2001), 27.
} 


\section{Dampak Menjadi Hamba}

Sesuai dengan arti dan fungsinya di atas, maka sangat terasa dampak yang akan dialami oleh seorang hamba, yaitu menjadi budak dan mengerjakan hal-hal yang diperintahkan serta tidak dipedulikan dirinya sendiri. Menjadi pribadi yang hidup dalam tekanan, tidak berhak sepenuhnya atas dirinya dan hidup di bawah perbudakan. Dirinya bukan miliknya sendiri lagi, tetapi milik tuannya, artinya bahwa diri dan hidupnya dikendalikan oleh perintah tuannya dan tidak bebas menentukan sesuatu atas dirinya.

Hamba adalah orang yang dianggap rendah, miskin dan terbelakang. Tidak dipandang dalam masyarakat jika ia berada pada suatu kumpulan warga masyarakat. Hamba selalu tidak diinginkan apalagi menjadi seorang hamba atau budak bagi orang lain, namun demikian ada hal yang positif yang dapat ditarik dari seorang hamba, yaitu "Selalu berhubungan dengan pelayanan yang sedang diberikan kepada sesama, berhubungan dengan hal-hal yang sangat perlu untuk hidup wajar di dunia dan dalam suatu hubungan yang sangat pribadi." ${ }^{21}$ Merupakan pekerjaan yang mulia jika seorang hidup dan menjadi berkat di tengah-tengah kumpulan orang ataupun seseorang yang menjadi fokus pemberkatannya. Seorang hamba atau budak menjadi berkat bagi tuannya, seorang palayan menjadi berkat bagi siapa saja yang ia layani. Inilah yang diharapkan dan diinginkan oleh Yesus bahwa menjadi berkatlah bagi orang lain dengan cara melayani mereka dan mengabdi kepada siapa saja yang membutuhkan bantuan. Karena melayani dan menjadi hambalah yang menentukan seseorang menjadi terkemuka, terbesar dan menjadi seorang pemimpin menurut Matius 20:26-27.

\section{Ada Harga yang Harus Dibayar (Matius 20:28)}

Matius 20:28, "Sama seperti Anak Manusia datang bukan dilayani, melainkan untuk dilayani dan memberikan nyawa-Nya menjadi tebusan bagi banyak orang."

Kata harga dalam Kamus Besar Bahasa Indonesia ialah nilai yang dibayar untuk sesuatu tertentu untuk memperoleh sesuatu. Dalam Kamus Besar Bahasa Indonesia kata harga mrmpunyai beberapa pengertian, namun dalam hal ini penulis mengutip satu di antara pengertian itu, yaitu "Kehormatan diri." 22 Jadi, dalam kaitannya dengan kepemimpinan hamba, maka harga yang dimaksud di sini adalah kehormatan seseorang yang ingin menjadi pemimpin yaitu pemimpin Kristen di mana ia harus turut berpikir serta berjuang untuk tidak menuntut satu kehormatan dari orang lain. Dalam pengertian lain, kata harga menunjukkan kepada

\footnotetext{
${ }^{21}$ A. Noordegraaf, Orientasi Diakonia Gereja (Jakarta: BPK Gunung Mulia, 2004), 4.

${ }^{22}$ Kamus Besar Bahasa Indonesia, s.v. "Harga” (Jakarta: Balai Pustaka, 2001), 388.
} 
suatu pengorbanan yang siap dilakukan oleh seseorang untuk melaksanakan sesuatu, secara khusus seorang pemimpin karena sudahlah pasti bahwa dalam setiap kepemimpinan sering kali diperhadapkan dengan situasi-situasi yang sulit, di situlah dibutuhkan sebuah harga pengorbanan yang harus dibayar. Dalam sebuah pelayanan kepemimpinan tentunya diharapkan suatu keberhasilan, namun tentunya di dalam meraih sebuah keberhasilan ada harga yang harus ditanggung dan dibayar. Dr. Frederick Price berkata, "Jika Anda mau berhasil dalam pelayanan, bersedialah untuk dikecam. Anda akan menderita serta dianiaya." ${ }^{23}$ Inilah sebagian harga yang harus ditanggung dan dibayar dari seseorang yang ingin berhasil dalam sebuah kepemimpinannya, ia juga harus membayar harga dengan cara rela menyangkal diri, menyadari bahwa ia bukan hanya menjadi seorang yang hanya dilayani, tetapi ia juga harus rela berkorban bagi orang lain atau bawahannya.

Ada beberapa bahasan tentang harga yang harus dibayar oleh setiap orang yang ingin menjadi pemimpin dan yang sudah menjadi pemimpin karena dalam setiap kepemimpinan pasti ada harga yang harus dibayar. Berikut ini harga yang harus dibayar dalam sebuah kepemimpinan hamba berdasarkan teladan Yesus Kristus menurut Injil Matius 20:28.

\section{Rela Menyangkal Diri Sendiri}

Secara terang-terangan Yesus selalu tidak menyebutkan diri-Nya sebagai Mesias atau Anak Allah atau Allah, namun kebanyakan Ia memakai ungkapan "Anak Manusia." Ensiklopedi Alkitab Masa Kini menjelaskan, "Yesus sering menyebut diri-Nya Anak Manusia yang menerangkan watak dan misi-Nya. Sebutan khas ini mengacu pada diriNya berkaitan dengan keharusannya menderita dan mati di kayu salib." ${ }^{24}$ Dari ungkapan ini jelas bahwa secara tidak langsung Yesus tidak ingin menunjukkan atau membesar-besarkan dirinya sebagai Raja dan Tuhan bagi orang lain pada waktu itu begitu pula kepada murid-murid-Nya. Yesus tidak menunjukkan diri-Nya sebagai raja dan Allah, secara tidak langsung Yesus sedang "menyangkal" diri-Nya demi misi-Nya dan watak kerendahan hati dan belas kasih-Nya bagi dunia ini sehingga Ia rela menyangkal diri dan menjadi sama seperti manusia sekalipun Dia adalah Allah dan Raja Yang Maha tinggi.

\footnotetext{
${ }^{23}$ Frederic K. C. Price, Saran-saran Praktis Untuk Pelayanan yang Berhasil, (Jakarta: Immanuel, 1993), 35.

${ }^{24}$ Ensiklopedi Alkitab Masa Kini Jilid II, (Jakarta: Yayasan Komunikasi Bina Kasih, 1992), 586.
} 
Setelah Yesus mengajar para murid mulai dari ayat 26-27, maka pada ayat 28 ini Yesus menjelaskan dan menghubungkan diri-Nya dengan cerita pengajaran-Nya itu, yaitu bahwa "Sama seperti Anak Manusia datang bukan untuk dilayani, melainkan untuk melayani dan untuk memberikan nyawa-Nya menjadi tebusan bagi banyak orang." Ungkapan "sama seperti Anak Manusia" yang disebut oleh Yesus sepertinya mengarah kepada orang ketiga, yaitu selain murid-murid-Nya dan Yesus sendiri. Yesus menutupi diri-Nya yang seharusnya Ia berterusterang menyatakan bahwa sebenarnya Ia sendiri yang dimaksud-Nya, tetapi Ia merendahkan diri-Nya dengan jalan "menyangkal diri" demi suatu maksud-Nya yang mulia.

\section{Bukan untuk Dilayani, Melainkan untuk Melayani}

Yesus membuktikan pernyataan-Nya ini bahwa Dia datang bukan untuk dilayani, melainkan untuk melayani. Oswald Sanders dalam bukunya Kepemimpinan Rohani menulis, "Secara sempurna Tuhan telah menggambarkan ajaran-Nya sendiri dengan teladan: Karena Anak Manusia juga datang bukan untuk dilayani, melainkan untuk melayani. Tetapi Aku ada di tengah-tengah kamu sebagai pelayan (Luk 22:27)." ${ }^{25}$ Jadi, Yesus datang dengan berbuat demikian agar menjadi teladan dalam hal pelayanan dan melayani. Dr. Frederick K. C. Price berkata, "Sebagai pelayan Injil, kita harus menjadi teladan bagi orang-orang yang ditempatkan Allah di bawah pengawasan kita. Itulah yang saya coba lakukan dalam segala sesuatu yang saya tangani." ${ }^{26}$ Setiap orang yang menjadi pemimpin atau terkemuka dalam lingkungannya atau kelompoknya ia dituntut untuk bisa menjadi teladan yang sama dengan pola Yesus, yaitu tidak dilayani oleh orang lain, tetapi melayani orang lain dan menjadi teladan yang baik.

Ungkapan "bukan untuk dilayani, melainkan untuk melayani" adalah satu pernyataan yang saling bertolak belakang dan tidak bisa diterapkan secara bersamaan, jika dilayani, maka harus dilayani tanpa harus melayani dan jika melayani harus melayani tanpa dilayani. Ungkapan ini juga mengacu kepada suatu kerendahan hati, tatkala seseorang melayani orang lain, maka yang akan terlihat dan dirasakan adalah kerendahan hati, yaitu bersedia melayani orang lain. Andrew Murray menjelaskan, "Ia telah merendahkan diri-Nya dan taat sampai mati bahkan sampai mati di kayu salib (Fil 2:8). Kerendahan hati-Nya menjadi dasar dan akar hubungan dengan Allah dan karya penebusan-

\footnotetext{
${ }^{25}$ Oswald Sanders, Kepemimpinan Rohani, (Bandung: Kalam Hidup, 2001), 13.

${ }^{26}$ Frederic K. C. Price, Saran-saran Praktis Untuk Pelayanan yang Berhasil, (Jakarta: Immanuel, 1993), 35.
} 
Nya." ${ }^{27}$ Kerendahan hati Yesuslah yang membuat Ia mau melayani dunia dan bukan dilayani oleh dunia yang akhirnya berpuncak pada kematianNya di kayu salib yang menjadi tebusan bagi banyak orang.

\section{Memberikan Nyawanya Bagi Orang Lain}

Tafsiran Alkitab Masa Kini memberi penjelasan, "Di sini ditempatkan secara berdampingan kerendahan hati Yesus, penderitaan hamba Tuhan, dan kebesaran-Nya sebab dapat mengorbankan diri-Nya supaya semua orang mendapat kebebasan dari dosa mereka." ${ }^{28}$ Karya termulia dan teragung yang terbesar yang telah dilakukan oleh Yesus adalah merelakan nyawa-Nya menjadi tebusan bagi dunia. Dari kutipan di atas jelaslah bahwa oleh karena kerendahan hati dan kebesaran Yesuslah yang membuat Ia harus memberikan nyawa-Nya bagi tebusan banyak orang. Dan inilah yang menjadi alasan terkuat bagi manusia untuk memberikan hal yang terbaik dalam hidupnya untuk orang lain, mungkin pegorbanan itu tidak persis seperti yang telah dilakukan oleh Yesus, namun apa yang terbaik yang bisa dibuat bagi orang lain tanpa sungut-sungut serta tidak menuntut balas dan sekalipun nyawa yang menjadi taruhannya itulah yang merupakan pengorbanan.

Seorang Kristen ditunut agar tidak mementingkan dirinya sendiri, tetapi hendaklah ia menjadi berkat bagi orang lain dan mengasihi mereka sebagaimana mengasihi dirinya sendiri. Memberikan nyawa bagi orang lain adalah suatu ungkapan yang menunjukkan suatu pemberian yang serius dan sepenuhnya tanpa tersisa dan yang tulus. Pdt. Dr. Rainer Scheunemann berkata, "Tidak mencari keuntungan sendiri dan rakus. Sebagai seorang pemimpin tidak boleh egois. Orang-orang melihat halhal yang sederhana ini, dan karakter kita yang sebenarnya terlihat dalam hal-hal ini." ${ }^{29}$ Inilah penjelasan dari Pdt. Dr. Rainer Scheunemann. Jadi, jika seseorang tidak berani berkorban ataupun bayar harga demi orang lain, maka ia sebenarnya berada pada posisi yang berlawanan dengan prinsip dan pola Yesus yaitu rela memberikan nyawanya bagi orang lain.

Memberikan nyawa bagi orang lain juga merupakan pengorbanan pelayanan yang dilakukan oleh seorang pelayan atau pemimpin gereja bagi jemaat dan bawahannya. Mengorbankan sesuatu dan memberikan nyawa bagi orang lain tidak ada gunanya jika tidak dilakukan dengan sikap rendah hati. Oleh sebab itu, Andrew Murray menjelaskan, "Kerendahan hati di hadapan Allah tidak berarti apa-apa bila tidak

\footnotetext{
${ }^{27}$ Andrew Murray, Kerendahan Hati, (Yogyakarta: Yayasan Andi, 1994), 7.

${ }^{28}$ Tafsiran Alkitab Masa Kini,( Jakarta: Yayasan Komunikasi Bina Kasih, 1983), 106.

${ }^{29}$ Rainer Scheunemann, Pertumbuhan Jemaat Menuju Jemaat yang Misioner, (Papua: Sekolah Alkitab Malam Gereja Kristen Injili di Tanah Papua, 2004), 28.
} 
terbukti dalam kerendahan hati di hadapan sesama kita." ${ }^{30}$ Maksudnya ialah jika kerendahan hati dalam pelayanan kepada manusia tidak nyata, maka tentu kepada Allah tidak berarti sebuah pengorbanannya.

\section{RELEVANSI KEPEMIMPINAN HAMBA PADA MASA KINI}

Relevansi merupakan kata benda yang artinya, "Kait-mengait; bersangkut-paut; berguna secara langsung." ${ }^{11}$ Sedangkan kata relevan sendiri artinya "Hubungan; kaitan." 32 Jadi dalam kaitannya dengan kepemimpinan hamba, maka tentulah hal itu mempunyai hubungan dan pengaruh yang kuat bagi kepemimpinan pada masa kini, yaitu dalam kepemimpinan gereja, kepemimpinan Kristen serta kepemimpinan dalam keluarga atau dalam rumah tangga Kristen.

\section{Relevansi Kepemimpinan Hamba Pada Gereja Masa Kini}

"Berbicara tentang gereja pada zaman ini, merupakan suatu percakapan yang sangat memprihatinkan meskipun pembicaraan tentang pokok tersebut sangat manarik dan menantang." ${ }^{33}$ Gereja akhirakhir ini memiliki persepsi yang berbeda-beda sesuai dengan dokma/ajaran masing-masing gereja yang akhirnya seperti kutipan di atas bahwa menuju pada suatu keprihatinan karena tidak jelas dan tidak sesuai dengan pola alkitab itu sendiri, walaupun mungkin tidak semua gereja. Dalam bukunya Kerajaan Allah dan Gereja Pdt. Dr. Eddy Paimeon menambahkan, "Secara teoritis dan teologis gereja adalah suatu bangunan rohani yang berpondasikan Kristus atau gereja adalah tubuh Kristus, namun pada kenyataannya bangunan ini sudah hancur menjadi puing-puing kecil yang telah berserakan." ${ }^{4}$

Gereja dalam kata Ibrani ialah "qahal semata-mata berarti sejumlah orang yang berhimpun bersama dan biasanya dalam septuaginta diterjemahkan sebagai ekklesia. Dalam

Alkitab bahasa Indonesia diterjemahkan orang-orang kudus." ${ }^{35}$ Jadi, yang dimaksud di sini ialah bahwa kepemimpinan hamba itu sangat relevan bagi gereja atau sejumlah orang dalam kumpulan orang-orang kudus yang berhimpun pada suatu tempat yang disebut gedung gereja.

\footnotetext{
${ }^{30}$ Andrew Murray, Kerendahan Hati, (Yogyakarta: Yayasan Andi, 1994), 42-43.

${ }^{31}$ Kamus Besar Bahasa Indonesia, s.v. "Relevan” dan "Relevansi," (Jakarta: Balai Pustaka, 2001), 943.

${ }^{32}$ Ibid., 943.

${ }^{33}$ Eddy Paimeon, Kerajaan Allah dan Gereja, (Bandung: Agiamedia, 1999), 51.

${ }^{34}$ Ibid., 51.

${ }^{35}$ Charles C. Ryrie, Teologi Dasar Jilid II, (Yogyakarta: Yayasan Andi,1992), 184.
} 
Pembahasan ini lebih dicondongkan pada sikap pemimpin gereja yang ada pada setiap gereja dalam hal ini gembala serta pengerja atau pelayan gereja lainnya, bagaimanakah sikap yang harus diambil dalam sebuah pelayanan berdasarkan ciri-ciri kepemimpinan hamba?

\section{Hamba yang Melayani}

Sebagaimana layaknya seorang hamba yang bekerja pada tuannya, maka sebagai seorang pengerja gereja pun seharusnya melayani sebagaimana seorang hamba atau budak kepada Tuhan Yesus. Seorang pengerja gereja mempunyai tuan, yaitu Tuhan Yesus yang hanya kepadaNya saja ia mengabdi dan menghabiskan seluruh hidupnya, pelayanan yang dikerjakan hanya untuk Tuhan dan sesuai dengan Firman-Nya atau yang dapat disebut sebagai perintah Tuhan sendiri. Gembala sidang serta pengerja gereja lainnya harus selalu menjalankan/mengerjakan perintah Tuhan Yesus apa pun resikonya, ia tidak bekerja semaunya, tetapi bekerja seturut perintah dan Firman Tuhan. Oswald Sanders menulis, “... kepemimpinan dalam arti memberikan pelayanan yang sebesar-besarnya." 36 Seorang pengerja gereja adalah pemimpin yang harus memberikan pelayanan yang sebesar-besarnya kepada Tuhan melalui pelayanannya yang kelihatan, yaitu melayani jemaat Tuhan pada gereja lokal.

Dasar menjadi seorang pemimpin yang kokoh adalah berani menjadi hamba yang melayani. Sebelum dipercayakan hal-hal yang besar kepadanya, setidaknya ia harus mulai dari hal-hal kecil dan yang terendah sekalipun bahkan mungkin terhina di mata orang lain sebab dalam Firman-Nya Yesus berkata, "Barangsiapa yang ingin menjadi terkemuka di antara kamu, hendaklah ia menjadi hamba untuk semuanya (Matius 20:27)." Hamba merupakan pembantu atau budak yang tidak punya harga diri dan tidak berhak atas dirinya dan hanya bergantung serta berharap sepenuhnya kepada tuannya. Teladan serta perintah yang diberikan oleh Yesus di dalam Yohanesl3:14, "Jadi, jika Aku membasuh kakimu, Aku yang adalah Tuhan dan Gurumu, maka kamu pun wajib saling membasuh kakimu." Otoritas perintah, teladan dan setiap pemikiran, baik tentang ketaatan ataupun perbuatan menjadikan kerendahan hati menjadi unsur pemuridan yang paling mendasar dan pertama." ${ }^{\text {37 }}$ Yesus memberikan perintah agar setiap pelayan pun harus saling melayani dan memperlengkapi untuk menjadi hamba yang mampu melayani lebih lagi.

\footnotetext{
${ }^{36}$ Oswald Sanders, Kepemimpinan Rohani, (Bandung: Kalam Hidup, 2001), 27.

${ }^{37}$ Andrew Murray, Kerendahan Hati, (Yogyakarta: Yayasan Andi, 1994), 28.
} 
Peniel Maiaweng menjelaskan, "Kata melayani yang terdapat dalam Matius 20:28 diterjemahkan dari kata diakonesai (asal kata diakoneo), yang berarti menyiapkan makanan atau kebutuhan hidup; mengadakan pemeliharaan dan mencukupkan kebutuhan seseorang untuk memperpanjang hidupnya; atau menyiapkan keperluan-keperluan untuk

Para pemimpina gereja dan pengerja gereja saat ini dituntut untuk bisa melayani kepala gereja, yaitu Tuhan sendiri. Namun ia juga dituntut untuk bisa peduli kepada siapa yang dipimpin dan siapa yang kepadanya dipertanggungjawabkan pelayanannya. "Jemaat dipandang sebagai kawanan domba yang lemah dan mudah sesat yang perlu didampingi dan digembalakan." 38 Oleh sebab itu, gembala jemaat dan pengerja gereja perlu memberikan pelayanan serta kepedulian yang optimal agar mereka dikuatkan dan tidak tersesat dan disesatkan oleh hal-hal yang membahayakan iman percaya mereka dan secara khusus bagi keselamatan mereka, dengan demikian mereka mendapatkan kenyamanan serta memperoleh damai sejahtera di dalam Tuhan Yesus. Dr. Benny Giay menambahkan, "Petugas gereja itu memandang dirinya sebagai gembala yang paham permasalahan yang sedang menjaga dan melindungi warga jemaatnya dan memahami kebutuhan mereka secara spiritual dan keadaan kawanan domba tadi dan berupaya memenuhi kebutuhan para domba." ${ }^{39}$ Jadi, para gembala seharusnya tahu dan paham tentang segala hal yang terjadi dan yang dialami oleh dombanya atau jemaat, dan ditambahkan bahwa bukan hanya sampai pada titik pemahaman, melainkan terus berlanjut sampai pada upaya pemenuhan kebutuhan para domba atau jemaat yang dilayaninya. Inilah fungsi seorang gembala dan para pengerjanya serta hal-hal yang dilaksanankan dalam kepeduliannya terhadap jemaat. Rick Warren mengatakan, "Banyak penelitian telah memperlihatkan bahwa alasan-alasan orang memilih bergereja di tempat tertentu adalah karena mereka merasa simpati kepada gembala sidang." ${ }^{40}$ Salah satu penyebabnya ialah kepedulian seorang gembala terhadap domba-domba yang lain juga dan bukan hanya dombanya atau anggotanya.

Kepedulian yang dimaksud di sini juga ialah bahwa sebagaimana seorang hamba yang melayani dengan sepenuh hati dan memfokuskan segala keberadaannya kepada tuannya, maka layaklah juga bagi seorang gembala serta hamba-hamba Tuhan hari ini untuk menyerahkan seluruh hidupnya bagi kepedulian dan pelayanan Tuhan dengan penuh tanggung jawab dan dengan sepenuh hati yang dibuktinyatakan lewat pelayanan

\footnotetext{
${ }^{38}$ Benny Giay, Gembalakanlah Umat-Ku, (Jayapura: Deiyai, 1998), 154.

${ }^{39}$ Ibid., 154.

${ }^{40}$ Rick Warren, Pertumbuhan Gereja Masa kini, (Malang: Gandum Mas, 2003), 181.
} 
terhadap jemaat Tuhan hari ini tanpa mengutamakan materi dan motivasi yang salah.

\section{Relevansi Kepemimpinan Hamba Dalam Kepemimpinan Kristen Masa Kini}

Akibat yang akan timbul dari sebuah relevansi hamba terhadap kepemimpinan Kristen adalah kepemimpinan Kristen akan menempatkan posisinya di dalam kepemimpinan hamba. Artinya bahwa seorang pemimpin Kristen seharusnya menempatkan diri dan posisinya sebagai pemimpin yang melayani atau menghamba. Secara umum seorang pemimpin haruslah menjadi orang dihormati dan dilayani oleh para pengikutnya. Tanpa hak-hak serupa itu, maka seorang pemimpin dirasakan tidak akan dapat melaksanakan tugasnya dengan baik. Semakin berwibawa seorang pemimpin, semakin orang merasakan kepemimpinnya. Ia dapat menjadi pemimpin yang melayani bila memiliki hati yang melayani. Seorang pemimpin hamba hanya dapat melakukan hal itu bila ia menghayati makna perannya sebagai orang yang melayani. Sebagai seorang pemimpin Kristen dalam suatu organisasi tertentu, maka ia harus bisa melayani dan tidak harus monoton memerintah bawahannya.

Dalam menjalankan fungsinya sebagai seorang pemimpin Kristen yang sekaligus menjalankan fungsi seorang hamba, maka ada dua hal yang terdapat dalam kaitannya dengan kepemimpinan Kristen yang diambil berdasarkan Matius 20:28, yakni pemimpin yang jujur dan pemimpin yang siap bayar harga.

\section{Pemimpin yang Jujur}

Sebelum dibahas tentang kepemimpinan yang jujur sebaiknya dimengerti terlebih dahulu kata jujur. Jujur berarti, "Lurus hati tidak berbohong; tidak curang dan tulus, ikhlas." ${ }^{41}$ Kejujuran mempunyai hubungan yang erat dengan integritas seseorang apalagi seorang pemimpin terutama seorang pemimpin Kristen. Fred Smith berkata, "Integritas dimulai dengan motivasi. Saya tidak bisa benar-benar jujur karena saya orang berdosa, tetapi saya bisa mencegah diri saya untuk tidak melakukan ketidakjujuran. Ketidakjujuran adalah sebuah

\footnotetext{
${ }^{41}$ Kamus Besar Bahasa Indonesia, s.v. "Jujur” (Jakarta: Balai Pustaka, 2001), 479.
} 
keputusan." ${ }^{42}$ Fred Smith secara tidak langsung ingin berkata bahwa apa yang dikatakan atau setiap perkataan seorang pemimpin Kristen seharusnya sejalan dengan tindakannya atau apa yang dilakukannya. Atau dengan kata lain jika harus dikatakan "Ya", maka harus "Ya" juga tindakannya dan jika "Tidak", maka harus "tidak" pula seperti itu dalam bertindak.

George Barna, berkata,

Seorang pemimpin Kristen adalah orang dengan karakter seperti Kristus. Karena fungsi utama pemimpin ini adalah memungkinkan orang-orang mengenal, mencintai dan melayani Tuhan dengan sepenuh hati, pikiran, jiwa dan kekuatan, maka pemimpin itu sendiri harus memiliki sifat-sifat pribadi, karakter hati yang dimanifestasikan melalui ucapan dan perilaku yang merefleksikan sifat Tuhan kita. ${ }^{43}$

Ada beberapa dan mungkin banyak sifat-sifat Yesus yang seharusnya diikuti oleh semua orang percaya terutama seorang pemimpin Kristen, namun dalam penulisan ini penulis hanya membatasi pada sifat kehambaan Yesus dalam hal melayani. Salah satu sifat yang dibutuhkan dari seorang pemimpin Kristen adalah kejujuran dalam memimpin dan keterbukaan. Seharusnya sejalan apa yang dikatakan dengan apa yang dilakukan, tetapi hal itu juga harus sesuai dengan ketulusan hati atau karakter hati seperti yang dikatakan oleh George Barna di atas. Pada bagian lain Sendjaya menulis, "Pakar kepemimpinan Warren Bennis mengatakan bahwa intergritas adalah fondasi untuk membangun rasa percaya (trust)." "44 Selanjutnya Sendjaya menulis dalam bukunya Kepemimpinan Kristen, "Integritas dimengerti sebagai keutuhan, yang dimaksud adalah keutuhan dalam seluruh aspek hidup, khususnya antara perkataan dan perbuatan." ${ }^{45}$ Ketika seorang pemimpin Kristen mengalami keganjalan antara kedua hal ini, maka kemungkinan besar ia tidak jujur dan berdampak pada ketidakpercayaan yang ditimbulkan dari orang lain secara khusus bawahannya.

Seorang pemimpin Kristen dalam suatu lembaga ataupun organisasi-organisasi mana pun, seharusnya menunjukan jati diri sebagai seorang pemimpin Kristen yang berhati hamba sebagaimanan Yesus.

\footnotetext{
${ }^{42}$ Fred Smith, Memimpin Dengan Integritas (Jakarta: Immanuel, 2002), 19.

${ }^{43}$ George Barna, Leaders on Leadership, (Malang: Gandum Mas, 2002), 26-27.

${ }^{44}$ Sendjaya, Kepemimpinan Kristen: Konsep, Karakter, Kompetensi (Yogyakarta:Kairos Books, 2004), 62.

${ }^{45}$ Ibid., 63-64.
} 
Melayani bawahannya dengan jujur penuh kerendahan hati, sabar serta mengasihi mereka. Kejujuran tidak dapat dipisahkan dari diri seorang pemimpin Kristen dan integritas secara utuh dari seorang pemimpin Kristen saat ini sangat dibutuhkan. Eka Darmaputra memperlengkapi kejujuran itu dengan berkata, "Tapi kita tahu kejujuran saja tidak cukup. Kejujuran adalah kebajikan, ya, namun memerlukan kebijakan. Sebab kebenaran juga butuh pakaian." ${ }^{46}$ Artinya apa yang diyakini benar dan kemudian dikatakan itu harus dinyatakan lewat tindakan dan perbuatan.

\section{Pemimpin yang Siap Bayar Harga}

Dalam bukunya Sendjaya mengatakan, "Jika seorang pemimpin Kristen merasa bahwa tidak ada apa pun yang dituntut dalam hidupnya untuk menjalani panggilan Allah, maka panggilan tersebut perlu dipertanyakan otentitasnya." ${ }^{47}$ Jadi, dalam setiap kepemipinan terutama kepemimpinan Kristen pastilah ada hal-hal yang muncul di luar dugaan yang dapat berakibat baik dan buruk atau berakibat positif serta negatif.

Jika ditinjau kembali penulisan ini, maka sesungguhnya apa yang dibahas secara tidak langsung mengarah kepada sebuah harga yang telah dan harus dilakukan oleh seorang pemimpin Kristen dalam lingkup luas. Menjadi pelayan dan hamba bagi seorang pemimpin secara umum merupakan hal yang rancu dan tidak "normal". Karena jika seorang pemimpin menjadi pelayan, maka pemimpin itu merangkap dua pekerjaan sekaligus dan seolah-olah bawahannya yang seharusnya melayaninya menjadi seperti seorang pemimpin yang dilayani.

Pada setiap kepemimpinan selalu menginginkan suatu kualitas kinerja yang baik dan hasil akhir yang baik. Begitu pula seperti yang dikatakan oleh Yakob Tomatala tentang kepemimpinan Kristen, "Kepemimpinan ialah memobilisasi orang-orang lain untuk bekerja sama ke arah tujuan yang telah disepakati oleh pemimpin dan bawahan." ${ }^{48} \mathrm{Hal}$ inilah yang diharpkan dan menjadi tujuan pemimpin, namun dalam mencapai hal tersebut butuh pengorbanan, kesabaran dan ketekunan, karena untuk memobilasi orang dengan bermacam-macam karakter serta latar belakang yang berbeda-beda membutuhkan kesabaran dan penguasaan diri secara emosional dan psikologi. Karena pasti ada kekecewaan, kesalahpahaman, ketidaksamaan dalam pengambilan

\footnotetext{
${ }^{46}$ Eka Darmaputra, Kepemimpinan Dalam Perspektif Alkitabiah (Yogyakarta: Kairos Books, 2005), 31.

${ }^{47}$ Sendjaya, Kepemimpinan Kristen: Konsep, Karakter, Kompetensi (Yogyakarta: Kairos Books, 2004), 52.

${ }^{48}$ Yakob Tomatala, Kepemimpinan Kristen (Jakarta: Leadership Foundation, 2002), 32.
} 
keputusan, kemunafikan dicaci-maki serta pemberontakan dan lainnya. Sekalipun diperhadapkan dalam situasi demikian, maka pada saat itulah seorang pemimpin Kristen dituntut untuk bisa menerima situasi itu, sabar dan tetap melayani mereka sebagai seorang hamba yang patuh dan taat kepada tuannya. Inilah harga yang harus dibayar oleh seorang pemimpin Kristen.

\section{PENUTUP}

\section{Kesimpulan}

Berdasarkan seluruh pembahasan penulisan pada bab-bab sebelumnya, maka dapat ditarik beberapa kesimpulan sebagai berikut:

Pertama, kepemimpinan hamba mempunyai beberapa ciri-ciri khusus; pertama, harus menjadi pelayan. Artinya bahwa seorang pemimpin bukan saja hanya memimpin, tetapi juga harus membuktikan dirinya sebagai seorang pelayan. Kedua, harus menjadi hamba. Artinya bahwa seorang pemimpin bukan saja hanya memimpin orang dan memerintah saja, tetapi juga harus membuktikan dirinya sebagai seorang hamba yang merelakan diri sepenuhnya bagi kebutuhan bawahannya. Ketiga, ada harga yang harus dibayar, yaitu penyangkalan diri, bukan hanya menerima pelayan dari bawahan, tetapi juga merelakan diri dan hidupnya untuk melayani orang lain.

Kedua, kepemimpinan hamba masih dan sangat relevan bagi kepemimpinan saat ini, baik di dunia kepemimpinan sekuler, secara khusus dalam dunia kepemimpinan Kristen saat ini. Kepemimpinan Yesus sangat relevan dalam kepemimpinan gereja dan kepemimpinan pada lembaga-lembaga Kristen.

\section{KEPUSTAKAAN}

\section{Alikitab}

Ensiklopedi Alkitab Masa Kini jilid II. Jakarta: Yayasan Komunikasi Bina Kasih, 1992.

Ensiklopedi Alkitab Masa Kini. Jakarta: Yayasan Komunikasi Bina Kasih, 1992.

Tafsiran Alkitab Masa Kini Jilid 3. Jakarta: BPK Gunung Mulia,1983.

Kamus

Kamus Besar Bahasa Indonesia, Jakarta: Balai Pustaka, 2001. 
Sutanto, Hasan. Interlinier Konkordansi Yunani-Indonesia. Jakarta: Lembaga Alkitab Indonesia, 2003.

\author{
Buku-buku
}

Barna, George. Leaders on Leadership. Malang: Gandum Mas, 2002.

Bergant, Dianne dan Robert J. Karris, Tafsiran Alkitab Perjanjian Baru. Yogyakarta: Kanisius, 2006.

Darmaputra, Eka. Kepemimpinan Dalam Perspektif Alkitabiah. Yogyakarta: Kairos Books, 2005.

Eims, Leroy. 12 Ciri Kepemimpinan yang Efektif. Bandung: Yayasan Kalam Hidup, 2003.

Giay, Benny. Gembalakanlah Umat-Ku. Jayapura: Deiyai, 1998.

Maiaweng, Peniel. Pemberdayaan Jemaat Menjadi Pelayan Jemaat. Tenggarong: Sekolah Tinggi Teologi Tenggarong, 2004.

Murray, Andrew . Kerendahan Hati. Yogyakarta: Yayasan Andi, 1994.

Noordegraaf, A. Orientasi Diakonia Gereja. Jakarta: BPK Gunung Mulia, 2004.

Paimeon, Eddy. Kerajaan Allah dan Gereja. Bandung: Agiamedia, 1999.

Price, Frederic K. C. Saran-saran Praktis Untuk Pelayanan yang Berhasil. Jakarta: Immanuel, 1993.

Ryrie, Charles C. Teologi Dasar Jilid II. Yogyakarta: Yayasan Andi,1992. Sanders, Oswald Kepemimpinan Rohani. Bandung: Kalam Hidup, 2001.

Scheunemann, Rainer. Pertumbuhan Jemaat Menuju Jemaat yang Misioner. Papua: Sekolah Alkitab Malam Gereja Kristen Injili di Tanah Papua, 2004.

Sendjaya, Kepemimpinan Kristen: Konsep, Karakter, Kompetensi. Yogyakarta: Kairos Books, 2004.

Smith, Fred. Memimpin Dengan Integritas. Jakarta: Immanuel, 2002.

Tomatala, Yakob . Kepemimpinan Kristen,.Jakarta: Leadership Foundation, 2002.

Warren, Rick. Pertumbuhan Gereja Masa KiniMalang: Gandum Mas, 2003. 